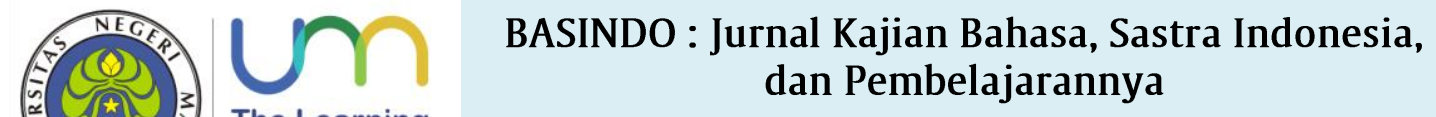

\title{
MENAPAKI LANGKAH HINGGA JEJAK NASIONALISME DALAM ROMAN JEJAK LANGKAH KARYA PRAMOEDYA ANANTA TOER
}

\author{
Dewi Masitoh", Muh. Fatoni Rohman \\ Fakultas Ilmu Budaya Universitas Brawijaya
}

\section{A R T I K E L}

Kata Kunci:

Nasionalisme

Kesadaran identitas

Rasa setiakawan

Mobilisasi organisasi

\begin{abstract}
A B S T R A K
Karya sastra merupakan produk rekam jejak peristiwa yang ada dalam masyarakat, baik masyarakat di lingkungan penulis maupun masyarakat lingkungan pembaca sebagai objek penceritaan. Penelitian ini bertujuan untuk mendeskripsikan peristiwa pergerakan nasional yang terjadi pada awal abad XX, melalui konsep nasionalisme dari sudut pandang politik guna mengetahui bentuk nasionalisme pada masa tersebut, sehingga mendapatkan kesimpulan apakah wacana keindonesiaan sudah muncul pada masa pra 1928. Tulisan ini menggunakan teori poskolonial Foulcher dan Day sebagai dasar pembatasan masa kolonial dan efek-efek yang ditimbulkan kolonialisme, dibantu dengan teori konsep nasionalisme Sartono Kartodirdjo, yang akan menjawab bentuk nasionalisme pada masa kolonial awal abad XX dan mengetahui hadir belumnya wacana keindonesiaan pada masa pra 1928. Hasil penelitian ini mengungkap bahwa bentuk nasionalisme pada awalnya muncul pada lingkungan keluarga. Menurut Pramoedya Ananta Toer (PAT) dalam roman Jejak Langkah (JL), keluarga seideologis adalah nasion pertama bagi Minke. Oleh karenanya, ia akan membela nasion tersebut jika ada pihak luar yang mengganggu. Selanjutnya ditemukan juga perluasan ideologi Minke dalam memandang nasion. PAT dalam JL menjelaskan bahwasannya antara tahun 1901-1912, perjuangan pergerakan nasionalisme sudah memunculkan bibit-bibit persatuan bangsa-ganda yang bertansformasi menjadi bangsa tunggal, yang dalam istilah JL bangsa Hindia Melayu Besar. Dari sini terlihat bahwa pada masa tersebut wacana keindonesiaan belumlah muncul. Hanya saja bibit-bibit kesadaran berbangsa dan bertanah air satu sudah ada dalam organisasi yang mencita-citakan bangsaganda bersatu.
\end{abstract}

(C) 2017 BASINDO Journal. All rights reserved

\section{PENDAHULUAN}

Istilah nasionalisme pertama kali digunakan di Jerman pada abad ke-15. Istilah tersebut diberikan kepada para mahasiswa untuk tidak melupakan nilai-nilai kedaerahan dan bahasa asal mereka. Sehingga di daerah baru atau di kampus baru mereka tetap menunjukkan rasa cinta mereka terhadap bangsa atau suku asal mereka (Fitrahayunitisna dan Zulvarina, 2017). Pemaknaan nasionalisme mengalami pergeseran sejak terjadinya revolusi Perancis pada tahun 1789. Pergeseran pemaknaan tersebut dilatarbelakangi oleh faktor yang berbeda antara bangsa yang satu dan bangsa yang lain. Hal tersebut menjadikan nasionalisme tidak hanya produk bagi dunia Barat, tetapi juga sudah merambah pada negara-negara Asia-Afrika sebagai label perjuangan (Adisusilo, 2009: 4).

Secara harfiah nation yang berasal dari bahasa Latin natio, yang diambil dari kata nascor yang berarti saya dilahirkan. Maka dari itu Ritter (1986) dan Barruel (dikutip dari Adisusilo, 2009: 4) memaknai nation sebagai "group of people born in the same place (sekelompok orang yang dilahirkan di suatu daerah yang sama)." Jika dipandang dari segi politk, Kartodirdjo (1994: 3) memandang nasionalisme sebagai ideologi yang terdiri atas prinsip kebebasan, kesatuan, sama rata, serta orientasi nilai kehidupan kelompok dalam mewujudkan pembentukan dan pelestarian negara nasional. Dengan demikian, nasionalisme pada awal pergerakan nasional dapat difokuskan pada tiga aspek, yakni kesadaran identitas, rasa kesetiakawanan melalui integrasi, dan mobilisasiorganisasi.

\footnotetext{
"Corresponding author.

E-mail addresses: dewima7@gmail.com (Dewi Masitoh), muh_fatoni@ub.ac.id (Muh. Fatoni Rohman)
} 
Tulisan ini mencoba untuk mengungkap jejak pertemuan kolonial guna mengetahui bentuk nation dan nasionalisme dalam roman Jejak Langkah. Apakah bentuk-bentuk nasionalisme yang ditawarkan PAT sudah sampai pada wacana keindonesiaan atau belum.

\section{METODE}

Penelitian ini menggunakan desain kualitatif dengan pendekatan strategi kritik sastra poskolonial yang merupakan cara untuk mengungkap bekas-bekas pertemuan kolonial, konfrontasi ras-ras, bangsa-bangsa, dan kebudayaan-kebudayaan yang berada di bawah hubungan kekuasaan yang tak setara. Dari sini dapat dikatakan bahwa pascakolonialisme dalam pengkajian sastra merupakan suatu strategi kritik yang digunakan untuk mengidentifikasi jejak kolonialisme, serta mengevaluasi sifat dan arti penting efek-efek terkstual dari jejak tersebut dalam teks-teks sastra (Foulcher dan Day (2006: 2-3).

\section{PEMBAHASAN}

Temuan dalam penelitian ini berupa kesadaran identitas nasionalisme Minke, tumbuhnya rasa kesetiakawanan, dan perlawanan yang dilakukan melalui mobilisasi organisasi. Ketiga temuan tersebut akan dibahas satu per satu pada sub bahasan berikut.

\section{Kesadaran Identitas Nasionalisme Minke}

Perasaan sangat mendalam tehadap suatu ikatan yang erat dengan tanah air, dengan tradisi-tradisi setempat, dan penguasa-penguasa resmi di daerahnya akan senantiasa hadir di sepanjang sejarah dengan kekuatan yang bebedabeda. Akan tetapi pada akhir abad ke-delapan belas Masehi, nasionalisme dalam arti kata modern menjadi suatu perasaan yang diakui secara umum. Seiring bejalannya waktu, nasionalisme semakin kuat perannya dalam membentuk segala aspek kehidupan, baik yang bersifat umum maupun yang bersifat pribadi. Dan pada masa akhir-akhir ini telah berlaku syarat bahwasannya setiap bangsa harus membentuk suatu negara, negaranya sendiri, dan bahwa negara tersebut harus meliputi seluruh bangsa. Dahulu kesetiaan tertinggi seseorang tidak ditujukan kepada negara kebangsaan, melainkan kepada berbagai macam bentuk kekuasaan sosial, organisasi politik atau raja feodal dan lain sebagainya. Berabad-abad lamanya cita-cita dan tujuan politik bukanlah negara kebangsaan, melainkan bangsa dan golongan-golongan etnis untuk menjamin perdamaian bersama.

Kesadaran identitas nasionalisme Minke bermula dari sebuah prinsip dan keinginannya untuk menjadi manusia bebas. Kebebasan tersebut telah menjadikan Minke menjadi seorang pribadi yang tidak mudah tunduk pada penguasa juga pada aturan-aturan yang membelenggunya. Adapun prinsip dan keyakinan Minke dapat terbaca dalam kutipan berikut ini.

"Aku datang untuk jaya, besar dan sukses. Menyingkir kalian, semua penghalang! Tak laku bagiku panji-panji Veni, Vidi, Vici. Diri datang bukan untuk menang, tak pernah bercita-cita jadi pemenang atas sesama.". (Jejak Langkah; 1)

Sebuah prinsip yang cukup berani, yakni menjadi manusia bebas yang sepenuhnya bebas. Tidak tunduk pada pihak Kolonial juga tidak pada sesama Pribumi. Bebas-berani merupakan sebuah prinsip hidup yang ia pilih. Pada dasarnya Minke memang menempatkan dirinya pada tataran manusia modern dan terpelajar. Ia mengukur modernitas dengan cara melihat sejauh mana ketidakterikatan dan ketidakbergantungan seseorang terhadap birokrasi pemerintah kolonial. Hal tersebut terlihat pada kata "Tak laku bagiku panji-panji Veni, Vidi, Vici" yang merupakan simbol atas kekuasaan Kolonial. Dari sini dapat dilihat bahwa Minke telah memperlihatkan posisinya dalam golongan atau kelompok sosial masyarakat, yakni kontra penjajah Belanda. Sedangkan munculnya kata "Diri datang bukan untuk menang, tak pernah bercita-cita jadi pemenang atas sesama", secara tersirat memperlihatkan penilaian Minke terhadap para elite Jawa yang digunakan pihak Belanda untuk diperah pengabdiannya sehingga melahirkan sebuah penindasan. Berkat kekuasaan yang dimiliki elite-elite Jawa, mereka mempunyai peluang untuk melanggengkan sistem feodalistik yang ditanam pihak Belanda, sehingga sudah menjadi hal yang lumrah ada golongan orang yang menindas sebangsanya sendiri atas nama jabatan, mereka merasa telah memenangkan hidup dan kehidupan orang-orang yang ada di bawahnya.

Dalam upaya menjadi manusia bebas, Minke memilih untuk hidup tidak di bawah bayang-bayang keluarganya yang darah biru. Meskipun ia adalah keturunan Priyayi, ia tidak mengakui kepriyayiannya karena tidak mau dianggap sebagai pembantu Gubermen layaknya teman-temannya di Stovia.Meski Stovia, bukanlah tempat yang dirasa cocok dengan dirinya, tetapi di sekolah tersebutlah Minke bertemu dengan seorang dokterjawa pensiunan yang secara langsung memberikan sumbangsih dalam penyadaran identitas nasionalisme dalam diri Minke.

Pertemuan dengan dokterjawa pensiuanan telah membawa benih-benih kesadaran pada Minke tentang pentingnya Hindia memiliki sebuah organisasi yang asli miliki Pribumi. Dalam seruan dokterjawa, berisi bahwa untuk mencapai kemajuan Hindia, hendaknya mencontoh Jepang, Tiongkok, dan orang-orang Cina di Jawa. Selain pertemuan dengan dokterjawa pensiunan, pihak yang memberikan sumbangsih semangat dalam membentuk sebuah organisai, yaitu dari kalangan keluarga dan sahabat. Hal tersebut terlihat dalam data berikut ini.

"Apabila setiap dari sebangsamu mati sebagai pahlawan seperti mereka dalam perang Puputan

Bali, dengan cara-cara yang modern.... Tapi bagaimana jalannya? Berorganisasi! Berorganisasi, sekarang juga! Pekik Mei, dokterjawa pensiunan itu, Ter Haar. Bagaimana caranya? Bagaimana? Bagaimanaaaaa? Mulailah, dan kau akan mendapat jawaban, mendengung kembali suara Mei beberapa tahun yang lalu. Aku tundukkan kepala, kembali ke meja kerja. Kukeluarkan buku catatan dan menulis kata-kata ini: 'Hari ini aku akan memulai' ." (Jejak Langkah: 255) 
Jung (dalam Sobur, 2003: 312) berpendapat bahwa pertumbuhan pribadi seseorang merupakan suatu proses dinamika dan proses evolusi sepanjang hidup. Seorang individu secara kontinyu akan berkembang dan belajar menuju realisasi diri. Sebuah perkembangan yang mengarah pada kepribadian dalam semua aspek: fisik, motorik, mental, sosial, dan moral. Sebuah kepribadian yang merupakan kesatuan aspek jiwa dan raga, yang menyebabkan adanya tingkah laku dan tindakan. Pembentukan pola kepribadian tersebut terjadi melalui proses interaksi dalam dirinya sendiri, juga dengan pengaruh-pengaruh dari lingkungan luar.

Setelah berpisah dengan Ter Haar dan ditinggal wafat oleh Ang San Mei, bayang-bayang kedua orang tersebut masih acap kali hadir dalam hidup Minke. Sejarah panjang saat masih hidup bersama dengan istrinya (Ang San Mei), Minke sering mendapat dorongan untuk memulai berorganisasi. Juga oleh Ter Haar yang sering memperlihatkan kebiadapan para penguasa terhadap pribumi. Senyawa kesadaran dari dokterjawa pensiunan, Ang San Mei, dan Ter Haar telah menyatu dalam realitas diri Minke. Oleh karena itu, pernyataan Minke "Hari ini aku akan memulai.", merupakan langkah awal dalam merealisasikan kebenaran yang ia yakini, bahwa bangsanya memang membutuhkan sebuah organisasi modern milik Pribumi sendiri. Masuknya Minke dalam lingkungan organisasi, memperlihatkan bahwa ia telah menemukan kelompoknya. Adapun kelompok-kelompok yang dimaksud yaitu sekelompok orang yang mendapatkan perhatian lebih dalam diri Minke yang menumbuhkan we-setiment atau rasa setia kawan yang hadir di antara kedua belah pihak.

\section{Tumbuhnya Rasa Kesetiakawanan}

Ditinjau dari segi sosial, motif nasionalisme tidak terlepas dari dua hal, yakni kelompok (we-group) dan perasaan-kita (we-sentiment). Kedua motif tersebut saling melengkapi dan bekerja secara padu dalam membentuk konstruk nasionalisme dalam diri Minke. Munculnya perasaan-kita dalam sebuah kelompok, menjadi sebuah elemen yang penting dalam memupuk solidaritas antara kedua belah pihak yang akan meminimalisir keegoisan hingga pengkhianatan dalam sebuah kelompok. Dalam hal ini, rasa setiakawan yang menumbuhkan jiwa nasionalisme Minke dapat dilihat dari berbagai segi, antara lain: keluarga seideologi, organisasi, dan jurnalistik.

Keluarga seideologi merupakan lingkungan pertama yang memberikan sumbangsih dalam pemupukan rasa kesetiakawanan dalam diri Minke. Pengaruh Mama (Nyai Ontosoroh) juga Ang San Mei berperan dalam membangun rasa peduli Minke terhadap rakyat sebangsanya. Hal tersebut dapat dilihat pada data berikut ini.

"Setidak-tidaknya, Nyo, biar masih dalam tingkat pemula kau sudah jadi penyuluh. Sia-sia menyesali kegagalanmu untuk jadi dokter. Kaulah Pribumi pertama," tulis Mama dari Wonocolo setelah menerima nomor-nomor pertama. Ia membayar langganan untuk dua tahun. Juga pencari langganan yang lebih banyak gagal daripada berhasil. "Penerbitanmu lebih banyak memberikan penyuluhan hukum dan peraturan. Banyak priyayi membutuhkan untuk dapat melanggarnya lebih mantap. Kau sendiri sudah jadi kurban hukum. Setidak-tidaknya ada hukum yang adil dan ada yang menindas. Peraturan memperkuatnya. Ingat kau waktu kena tindas dulu? Waspadalah, jangan sampai kau ikut menindas dengan penyuluhmu." (Jejak Langkah: 297)

Data di atas, menunjukkan bahwa di lingkungan keluarga, Minke mendapatkan dorongan untuk memikirkan bangsanya. Sebuah usaha memberikan penyuluhan tentang hukum dan peraturan yang dianjurkan Mama telah ia sebarkan lewat MP. Banyak kalangan yang merasakan manfaat atas penyuluhan tersebut. Pengetahuan terkait hukum dan peraturan yang ada di Hindia dengan cepat diketahui banyak kalangan di Hindia. Ketidaktahuan yang selama ini diderita bangsanya, lambat laun ia cerahkan lewat pengetahuan dan gagasan yang ia tulis dalam surat kabar Medan Prijaji. Dari keluarganya pula rasa we-sentiment Minke kepada bangsanya berkembang dalam dirinya. Berkat keluarganya pula ia menyadari bahwa bangsanya membutuhkan sebuah permulaan yang akan mengantarkan kepada perubahan. Permulaan yang tercatat dalam sejarah bahwasannya belum ada seorang Pribumi yang berhasil melawan kehendak Eropa. Dan kini, sejarah itu tercatat atas namanya. Hal tersebut tersirat dalam surat yang dikirimkan oleh Nyai Ontosoroh kepada Minke.

Kelompok kedua yang memberikan sumbangsih dalam penumbuhan rasa kesetiakawanan Minke, yaitu Organisasi Modern Syarikat Priyayi (SP) dan Syarikat Dagang Islam (SDI). Pada tahun 1906 di Hindia sudah mulai ada beberapa orang terpelajar Pribumi yang mendapatkan pendidikan menengah dan tinggi. Bergelut dengan serba-serbi Eropa menumbuhkan kesadaran para terpelajar dalam menyadari kekurangan pada bangsanya. Kekurangan itu meliputi pendidikan, ilmu dan pengetahuan, teknologi, serta peradaban lainnya. Perlawanan bersejata sudah mulai tidak mereka singgung lagi. Para terpelajar Pribumi sudah menganggap bahwa perang fisik sudah tidak sesuai dengan peradaban yang semakin modern. Semua perlawanan terhadap kekuasaan Kolonial belumlah terkonsep matang guna memajukan negeri dan bangsa sendiri. Sampai pada akhirnya, mereka tahu bahwa keunggulan Eropa terletak pada kemajuan ilmu, pengetahuan, dan organisasi (Toer, 1985: 106-107). Berkenalan dengan ilmu dan pengetahuan Eropa, justru menjadi akibat wajar dalam pencerminan nurani terkait ilmu dan pengetahuan. Hal inilah yang membedakan antara Minke sebagai manusia Jawa terpelajar yang bertransformasi menjadi manusia modern.

Kesadaran atas timpangnya perbedaan itulah yang mengantarkan Minke menyadari bahwa ketertutupan dan membatasi diri dari kemajuan zaman membuat Jawa semakin terbelakang dari segala aspek jika dibandingkan dengan Eropa. Dari sinilah Minke memulai aksinya untuk membawa bangsanya menyusul peradaban yang modern dengan berkiblat pada peradaban Eropa dengan membentuk organisasi modern milik Pribumi, serta mengentaskan kebodohan bangsanya dengan membantu mendirikan sekolah-sekolah.

Sebagai inisiator SP, Minke memberikan gagasannya untuk memajukan bangsanya, yakni dengan memberikan bantuan tempat tinggal, beasiswa pendidikan bagi orang-orang yang tidak mampu, juga buku bacaan, tidak hanya 
untuk siswa tetapi juga anggota SP. Akan tetapi, sangat disayangkan harapan-harapan tersebut pupus, karena organisasi SP tidak bisa tumbuh sesuai dengan harapan. Hal tersebut telihat pada data berikut.

"Sebaliknya 'Medan' berkembang semakin luas. Daya hidupnya mencukupi. Makin banyak soal-soal aktual diminta. Orang menghendaki lebih banyak lagi, dan lebih banyak lagi. Orang ingin mengetahui lebih luas di samping menghendaki kepentingannya diperjuangkan. Tidak melalui organisasi lagi, melalui pembabaran soal kepada umum demi akal waras. Orang menghadapkan perlindungan pendapat umum terhadap penganiayaan dan penindasan orang-orang atasan, penguasa kolonial putih dan coklat, dengan tulisan tercetak yang tidak akan berbaliklidah." (Jejak Langkah: 321)

Kemalangan menimpa SP, kehidupan organisasi yang semakin hari terlihat lesu, tidak berpengharapan, hingga sampai pada kepingsanan yang tidak akan bangun. Sedangkan Medan Priyayi (MP) mengalami perkembangan yang cukup membanggakan. Hal ini terjadi karena kesalahan dari awal yang tidak terdeteksi, yakni pada perekrutan anggota SP. Pemikiran dalam merangkul golongan Priyayi, golongan terpelajar, justru menjadi masalah utama yang dengan pasti menggerogoti tubuh organisasi. Dari sini terlihat antara SP dan MP kiranya ada sebuah perbedaan orientasi yang cukup signifikan. Hal itu dibuktikan dengan jatuhnya SP sama sekali tidak memengaruhi sepak kerja MP, meski keduanya sama-sama dilekati embel-embel priyayi dan lahir dalam satu garis keturunan jika dalam silsilah keluarga.

Berhentinya SP menjadi awal hidupnya Syarikat Dagang Islamiyah (SDI). Belajar dari pengalaman berorganisasi sebelumnya, menjadikan Minke semakin yakin dalam mencari alat pemersatu rakyat Hindia. Bukan dari kalangan priyayi, melainkan dari kalangan orang bebas. Bebas tidak memiliki kepentingan dengan pemerintah, juga tidak terikat pada jabatan Gubermen. Dalam hal ini, ia memilih kaum pedagang.

Latar belakang dipilihnya kaum pedagang tak lain karena perhatian Minke pada siaran-siaran resmi Gubermen tentang keadaan perekonomian di Hindia. Perdagangan yang di sepanjang pulau Jawa berangsur-angsur berpindah tangan dari Pribumi ke tangan Tionghoa. Cepatnya laju perdagangan juga menggeser dan mendesak para pedagang Arab. Hanya beberapa tempat saja yang masih dikuasai oleh Pribumi, di antaranya Solo, Yogya, Kudus, dan Tasikmalaya. Perdagangan batik di Sala dan Yogya yang setiap tahunnya mencapai peredaran sampai ratusan gulden, dimungkinkan akan menimbulkan perkelahian antar golongan untuk berebut dan mempertahankan usaha batik tersebut. Dari sinilah Minke sadar bahwa perdagangan adalah jiwa negeri. Meski negeri tandus asalkan perdagangannya subur, suatu bangsa juga akan subur layaknya bangsa Arab Saudi. Begitupun dengan negeri yang subur, tapi perdagangannya kacau, tentu bangsanya juga akan kacau dan miskin. Selain itu, terpilihnya kaum pedagang juga dipengaruhi oleh gagasan-gagasan dari gurunya yakni Sjeh Ahmad Badjened yang terlihat pada data berikut.

"Pedagang orang paling giat di antara umat manusia ini, Tuan. Dia orang yang paling pintar.

Orang menamainya juga saudagar, orang dengan seribu akal. Hanya orang bodoh bercita-cita jadi pegawai, karena memang akalnya mati. Lihat saja diriku ini. Jadi pegawai, kerjanya hanya disuruhsuruh seperti budak. Bukan kebetulan Nabi SAW pada mulanya juga pedagang. Pedagang mempunyai pengetahuan luas tentang ikhwal dan kebutuhan hidup, usaha dan hubungannya. Perdagangan membikin orang terbebas dari pangkat-pangkat, tak membeda-bedakan sesama manusia, apakah dia pembesar atau bawahan, bahkan budak pun, pedagang berpikiran cepat. Mereka menghidupkan yang beku dan menggiatkan yang lumpuh." (Jejak Langkah: 520)

Muchtarom (1988: 4-5) mengistilahkan pedagang dengan sebutan wong dagang atau saudagar yang berarti para pedagang kaki lima, lebih banyak berkumpul dalam kota-kota kecil atau pemukiman kota besar yang memainkan peranan penting sebagai lembaga ekonomi. Terlepas dari pengertian tersebut, Minke tidak hanya membatasi pedagang pada istilah "pedagang kaki lima" saja. Ia meluaskan pengertian bahwa setiap orang yang tidak hidup dari Gubermen, tapi dari usahanya sendiri dinamakan pedagang. Bagi Minke pedagang merupakan orang yang bebas, mereka berdagang dan berusaha dengan kekuatan sendiri di atas kakinya sendiri. Mulai dari berdagang jasa sampai preman. Mereka adalah orang-orang yang dinamis dapat bergerak ke segala penjuru, juga orang yang berpengetahuan praktis. Dari sinilah ia simpulkan bahwa para pedaganglah yang harus dipersatukan di bawah panji organisasi. Sedangkan dipilihnya unsur agama Islam, karena bagi Minke, Islam merupakan unsur pemersatu yang tersedia di Hindia (Toer, 2011: 12).

Lingkungan terakhir yang juga memberikan sumbangsih pemupukan rasa kesetiakawanan Minke, yaitu lingkungan jurnalistik atau surat kabar MP.Melalui MP, Minke memperlihatkan semangat jurnalisme pembelaan atas permasalahan yang dihadapi rakyat sebangsanya. Terutama dalam hal hukum.

"Dengan penuh kebanggaan sering aku berseru-seru dalam hati: Pribumi sebangsaku, sekarang

kalian punya harian sendiri, tempat kalian mengadukan hal kalian. Jangan ragu. Tak ada kejahatan yang

takkan malu dan tersipu pada penglihatan dunia! Kalian kini punya 'Medan', tempat menyatakan pendapat dan pikiran kalian, tempat di mana setiap orang di antara kalian dapat bertimbang rasa dan keadilan. Minke yang akan membawakan perkara kalian ke hadapan sidang dunia!"(Jejak Langkah:366)

Melalui pengetahuan dan pemahaman tentang hukum, Minke memberikan pembelaan terhadap rakyat sebangsanya yang membutuhkannya. Karena dia sadar bahwa tidak semua bangsanya tahu dan paham hukum yang sedang berlaku. Juga yang tahu dan paham hukum belum tentu bisa memakainya sebagai alat untuk membela diri sendiri juga rakyat sebangsanya.

Dari sini terlihat bahwa sejak dari awal Minke memainkan MP sebagai media pers yang berpolitik. Kesadaran dan kepeduliannya terhadap bangsanya, ia menjadikan MP sebagai alat perjuangannya untuk memihak dan membela bangsanya. Banyak pembelaan yang dilakukan para pahlawan salah satunya dengan berperang fisik. Tapi tidak bagi 
Minke, sebagai seorang terpelajar ia adalah pahlawan yang membela rakyat sebangsanya dan mempertahankan buminya dengan menggunakan pena dan pemikirannya yang tajam.

Tidak hanya persoalan hukum dan pemerintahan, MP juga ikut menyuarakan ketidakberesan di Hindia yang menurut Minke perlu dan harus diberitakan. Karena ia tidak mau, ketidakberesan tersebut seolah-olah sudah menjadi hal yang lumrah dan dianggap wajar. Dengan penuh kesadarannya, ia lekas menggunakan MP sebagai alat untuk menghapuskan kewajaran yang tidak semestinya tersebut. Berikut data yang menunjukkan ketidakberesan para penguasa di Hindia yang dianggap wajar.

"Itulah Hindia," tulis Mama dari Paris." Koran-koran tidak berani memberitakan kebenaran, takut digulung atau di berangus, sedang para Priyayi rakus sekaligus beku dalam jabatannya, seperti katamu sendiri, pembesar hanya tahu menghukum. Kehidupan dikuasai sassus. Setiap orang boleh jadi korbannya tanpa bisa membela diri. Hentikan itu, Nak. Bikin harianmu jadi satu-satunya di Hindia, melulu bekerja untuk kebenaran, untuk keadilan, untuk semua sebangsamu.".(Jejak Langkah: 362-363)

Feodalisme memang masih kokoh di bumi Hindia pada awal abad XX. Penyelewengan atas jabatan tidak kurang-kurangnya dirasakan Pribumi. Penindasan hingga perampasan harta dan wanita sering dilakukan oleh para penguasa. Hal tersebut telah menjadi pemandangan dan persoalan yang dianggap wajar terjadi bagi golongan Pribumi yang tidak memiliki kekuasaan. Ketidakberdayaan untuk menentang menjadikan pihak tertindas pasrah sekaligus mengumpat sistem yang dianggap lebih biadab dari orang yang melakukan kebiadaban. Banyak orang yang tidak berani menurunkan kekecewaan ke atas surat resmi, begitupun dengan birokrasi Hindia yang tidak akan memerhatikan aduan atas surat-surat tersebut. Tidak ada yang berani menyuarakan kejadian-kejadian semacam itu. Banyak orang yang tidak mau berurusan dengan para penguasa demi membela sebangsanya. Hal inilah yang membedakan MP dengan surat kabar lainnya. Rasa kepedulian terhadap Pribumi untuk memberangus feodalisme ia suarakan melalui MP.

\section{Mobilisasi Organisasi: dari Penyadaran Hingga Perlawanan}

Ideologi nasionalisme Minke pertama kali dipengaruhi oleh orang-orang disekitar. Dalam hal ini bukan dari keluarga intinya, melainkan dari orang-orang sekitar yang saya sebut sebagai keluarga seideologis. Dari sini dapat dikatakan bahwa kesadaran Minke terhadap we group bukan bermula dari keluarga yang berbasis genetik, melainkan dari keluarga yang berbasis ideologi. Bagi Minke, keluarga adalah nasionnya. Jika nasionnya diganggu oleh entitas lain, ia tidak akan tinggal diam, ia akan membela dan melindungi nasionnya tersebut

Setelah keluarga, pihak yang menjadi bagian dalam kesadaran we-group Minke adalah anaknya (MP dan SDI dalam hal ini). Sejak keluarnya Minke dari sekolah dokter, ia menenggelamkan diri dalam dunia organisasi dan jurnalistik. Tercatat bahwa ia mengikuti seruan dokterjawa pensiunan untuk membentuk sebuah organisasi. Dengan semangat yang berkobar, dokterjawa pensiunan menyuarakan tentang betapa beruntungnya menjadi terpelajar dengan ilmu dan pengetahuannya ketimbang orang yang tidak terpelajar.

Dari seruan dokterjawa pensiunan, Minke mulai menaruh perhatiannya terhadap kesadaran bangsa, seperti yang dicontohkan, yaitu gagahnya bangsa Jepang yang diperoleh dengan cara berorganisasi. Membangkitkan kesadaran bangsanya melalui pendidikan dan pengajaran. Ia juga mulai tahu arti dari organisasi modern (organisasi yang mendapat pengakuan dari Gubermen Hindia Belanda), juga organisasi dapat dikatakan sebagai badan hukum.

Lahirnya organisasi modern SP, SDI dan MP, menjadi sebuah tanda bahwa ideologi terkait nasion Minke mengalami perluasan, tidak hanya sebatas lingkup keluarga, tetapi juga sudah pada tataran masyarakat. Bersama MP, ia memperjuangkan kesejahteraan Pribumi yang tidak mendapatkan keadilan.

Keberanian dalam menyuarakan ketidakadilan atas penindasan penjajah mulai digalakkan untuk menuntut hak-hak bangsa terjajah. Melalui MP, diharapkan warga dunia mengetahui persoalan yang sedang terjadi di Hindia. Dengan dipilihnya strategi perjuangan melalui jurnalistik dalam membangun opini publik menjadi hal yang tepat, karena keterbatasan media yang dimiliki Pribumi, suara golongan terjajah terbungkam. Hadirnya MP di tengah-tengah Pribumi, bagaikan angin segar yang akan membawa kehidupan baru bagi Pribumi.

Selanjutnya, bersama-sama di bawah naungan organisasi SDI, kekuatan kaum lemah akan menggema dalam melawan Penjajah. Dengan menggunakan cara nonkooperatif yang bersifat radikal, Minke mengajak Pribumi untuk tidak menaati perintah dan hukum yang berlaku. Pedagang tidak lagi menjual barang dagangannya kepada penjajah begitupun sebaliknya, barang dagangan penjajah tidak akan dibeli oleh Pribumi. Tentara tidak bersedia untuk berperang, petani tidak bersedia membayar pajak. Pembangkangan adalah salah satu alat yang tepat untuk melawan penjajah. Bersama SDI Minke berduyun-duyun menggemakan pemboikotan. Hal tersebut terlihat jelas pada data berikut.

"Kau akan tahu, Tuan, di Hindia ini kaum yang lemah sudah mempunyai senjata. Namanya boycott. Tuan akan saksikan bagaimana boycott ini dimainkan oleh kami. Tunggu tanggal mainnya, Tuan Hadji, dan Tuan akan dengarkan kegemparannya dari benua selatan ini. Dunia akan rasakan gemanya: puluhan ribu anggota S.D.I. akan bikin syndikat gulung tikar. Dunia akan kekurangan gula." (Jejak Langkah: 628)

Pemboikotan yang diawali oleh kaum Samin, telah memberikan pengaruh besar pada Minke untuk mengikuti jejaknya dalam melakukan pemboikotan oleh SDI terhadap penguasa. Sebuah pemboikotan atau pembangkangan yang berlandaskan menuntut keadilan. Jika Penjajah boleh memaksakan kehendaknya terhadap Pribumi, maka Pribumi sebagai pihak terjajah juga memiliki hak yang sama untuk melaksanakan kehendaknya terhadap penjajah. Boikot 
merupakan senjata sangat ampuh yang dimiliki Pribumi untuk melumpuhkan sistem. Dengan boikot, tatanan sistem yang terbangun akan mengalami kepingsanan (Sariban, 2016: 324-325).

Bagi SDI, merangkul golongan Priyayi sebagaimana diterapkan SP tidak akan mampu membawa bangsa Hindia menjadi bangsa tunggal sebagaimana yang ia cita-citakan. Oleh karena itu, SDI melebarkan jangkauannya dengan merangkul golongan yang beragama Islam yang sudah jelas menjadi mayoritas di Hindia. Sedangkan adanya unsur bahasa Melayu tak lain adalah upaya Minke untuk memperluas SDI tidak hanya di Jawa atau di Hindia tetapi juga di luar Hindia.

"Pulang dari Sala segera kususun program baru untuk perluasan Syarikat ke seluruh bangsabangsa berbahasa Melayu di dalam dan di luar Hindia. Aku tambahkan dalam tulisan itu juga bangsa berbahasa Melayu di Sailan dan Afrika Selatan. Untuk sementara aku namai mereka semua bangsa Melayu-Besar." (Jejak Langkah: 699)

Dari sudut Pangemanan (Toer, 2011: 4), aksi pemersatuan bangsa Hindia yang dilakukan Minke bukan saja karena faktor 'dipengaruhi' malah sudah sampai pada dampak atas 'kekaguman' kepada revolusi Tiongkok. Dia bermimpi menyatukan bangsa-bangsa Hindia di Hindia dan di perantauan, di kawasan selatan Asia dan Afrika, layaknya Sut Yat Sen telah melakukan dengan bangsanya. Data di atas telah memperlihatkan bahwa pada masa akhir tahun 1912 wacana keindonesiaan memang belum muncul. Tetapi bibit-bibit persatuan berbangsa dan bernegara sudah mulai ada dalam setiap orang. Dan lagi-lagi Minke sebagai inisiator telah mulai mendapatkan titik cerah dalam mewujudkan cita-citanya menyatukan bangsa HIndia yang berwatak ganda menjadi bangsa tunggal yang ia namai dengan sebutan bangsa Melayu-Besar.

\section{KESIMPULAN}

Berdasarkan analisis temuan dan pembahasan terkait nasionalisme pada roman Jejak Langkah karya Pramoedya Ananta Toer, ditemukan bahwa pergerakan nasional pada masa Hindia Belanda sudah tidak lagi menggunakan cara-cara kuno, yakni perang fisik. Dari analisis yang dilakukan, pergerakan nasional yang cukup terlihat yakni melalui pers atau jurnalistik juga organisasi modern. Hasil analisis yang dilakukan penulis menunjukkan bahwa, kesadaran nasionalisme muncul menjadi akibat wajar dari pendidikan dan pengetahuan modern yang sudah mulai merambah di bumi Hindia Belanda. Hasil dari pendidikan dan pengetahuan tersebut menjadi modal awal Pramoedya Ananta Toer dalam memperkenalkan pergerakan nasional melalui tokoh Minke. Sebagai seorang terpelajar, pergerakan yang dilakukan Minke telah memerlihatkan bahwa perkembangan zaman memengaruhi perlawanan yang dilakukan pihak terjajah. Sebagai alat perjuangan, media massa dan organisasi dipilih tidak semata-mata untuk melawan pihak Kolonial, tetapi juga untuk memperkenalkan paham nasionalisme di bumi Hindia Belanda, yang pada awal abad XX masih belum terlalu dikenal oleh rakyat.

Berdasarkan temuan dan simpulan yang disajikan, terdapat beberapa saran kepada berbagai pihak di antaranya para pendidik/guru dan peneliti sastra. Pertama, bagi praktisi pendidikan diharapkan dapat mempertimbangkan roman JL karya PAT sebagai salah satu alternatif bacaan wajib dalam pembelajaran, khususnya pelajaran sejarah. Roman JL diharapkan mampu memberikan wacana sejarah pergerakan Indonesia dari sudut yang lain. Terutama pada bentuk-bentuk perjuangan, pemikiran, gagasan yang disampaikan oleh pengarang. Nilai-nilai sosial yang meliputi semangat juang, kepedulian atas sesama satu bangsa, hingga pemertahanan idealisme. Juga penghormatan kepada jasa para pahlawan. Kedua, bagi peneliti sastra lain yang akan melakukan analisis, terutama pada roman JL, diharapkan dapat mengembangkan penelitian ini lebih terperinci lagi. Salah satunya pembahasan tentang identitas setiap tokoh yang terlibat dalam pergerakan nasional.

\section{Daftar Pustaka}

Adisusilo. 2009 . Nasionalisme-Demokrasi-Civil Society. Jurnal Historia Vitae, Volume 23- No. 2, (halaman 1-15), (online) https://www.usd.ac.id/lembaga/lppm/f113/Jurnal\%20Historia\%20Vitae/ vol23no2oktober2009/NASIONALISME\%20sutarjo\%20adisusilo.pdf, diakses 1 Januari 2017

Fitrahayunitisna dan Zulvarina, P. (2017). The Efforts to Strengthen National Identity Through Ethical Value and Local Wisdom in Oral Literature. ISLLAC : Journal of Intensive Studies on Language, Literature, Art, and

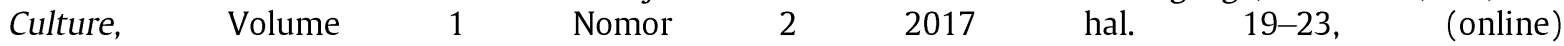
http://journal2.um.ac.id/index.php/jisllac/article/view/1918/1119, diakses 19 Desember 2017

Foulcher, K., \& Day, T. 2006. Clearing A Space: Kritik Pasca Kolonial tentang Sastra Indonesia Modern. Foulcher, K..\& Day, T (Eds.). Jakarta: Yayasan Obor Indonesia.

Kartodirdjo, S. 1994 . Pembangunan Bangsa: tentang Nasionalisme, Kesadaran, dan Kebudayaan Nasional. Yogyakarta: Aditya Media.

Muchtarom, Z. 1988. Santri dan Abangan di Jawa.Jakarta: INIS.

Sariban. 2016. Menemukan Keindonesiaan dalam Novel-Novel Pramoedya Ananta Toer. Lamongan: CV. Pustaka Ilalang Group.

Sobur, A. 2003. Psikologi Umum. Bandung: Pustaka Setia.

Toer, P. A. 1985. Sang Pemula. Jakarta: Hasta Mitra.

Toer, P. A. 2011. Rumah Kaca. Jakarta: Lentera Dipantara.

Toer, P. A. 2012. Jejak Langkah. Jakarta: Lentera Dipantara. 